\title{
Perkembangan Banjar Belaluan Sadmerta di Kota Denpasar tahun 1957-2017
}

\author{
Anak Agung Ngurah Putra Udayana*, I Ketut Ardhana \\ Prodi Sejarah, Fakultas Ilmu Budaya, Unud \\ [putra.udayana11@gmail.com] \\ *Corresponding Author
}

\begin{abstract}
This research choose the development of banjar Belaluan Sadmerta in Denpasar as its topic. There are two questions asked in this research which are, 1)What are factors behind establishment of banjar Belaluan Sadmerta, and 2) How's the development of banjar Belaluan Sadmerta in socio-cultural, religion, economy and politic in Denpasar within 1957-2017. This research used social history method by Kuntowijoyo, which is used to find out level of development. This research used Historical Theory by Ida Bagus Sidemen which explained, 1) Historical Explanation, 2) Historical Objectivity, 3)Historical Determinism. The theory used as basis in exploring and reconstructing data in this research. Development as concept, defined the development of banjar Belaluan Sadmerta to be perfect in both abstract and concrete forms. In this way, this research was able to produce conclusions from each research questions which then used as conclusion that the establishment of banjar Belaluan Sadmerta was inseparable from the dominant role of a sekaa or group and important society's figures in its development. Regional autonomy is also an opportunity for the societies to make banjar Belaluan Sadmerta as a place for societies to carry out daily activities.
\end{abstract}

Keywords : Development, Banjar, Belaluan Sadmerta, Denpasar City, Regional Autonomy.

\begin{abstract}
Abstrak
Penelitian ini memilih topik perkembangan banjar Belaluan Sadmerta di Kota Denpasar. Ada dua pertanyaan penelitian yang diajukan dalam penelitian ini yang terdiri dari, 1) Faktor-faktor apa yang melatarbelakangi berdirinya banjar Belaluan Sadmerta dan 2) Bagaimana perkembangan banjar Belaluan Sadmerta dalam bidang sosial budaya, agama, politik dan ekonomi di kota Denpasar kurun waktu 1957-2017. Maka dalam hal ini penulis menggunakan metodologi sejarah sosial Kuntowijoyo yang mana dalam metodologi ini mengkaji model Tingkat Perkembangan. Dalam penelitian ini juga digunakan teori ilmu sejarah yang dikemukakan Ida Bagus Sidemen yang mana teori ini menjelaskan, 1) Historical Explanation, 2) Historical Objektivity, 3) Historical Determinism. Teori tersebut dijadikan sebagai landasan berpikir dalam menggali dan merekonstruksi data dalam penelitian ini. Konsep perkembangan dalam banjar Belaluan Sadmerta diartikan menjadi bertambah sempurna dalam bentuk abstrak maupun konkret. Dengan cara seperti itu, studi ini mampu menghasilkan simpulan dari masingmasing pertanyaan penelitian yang kemudian diangkat menjadi sebuah intisari simpulan bahwa berdirinya banjar Belaluan Sadmerta tidak terlepas dari peran
\end{abstract}


dominan dari suatu sekaa atau kelompok dan tokoh penting masyarakat di dalam perkembangannya. Adanya peraturan otonomi daerah juga menjadi kesempatan masyarakat menjadikan banjar Belaluan Sadmerta sebagai wadah kelompok masyarakat dalam beraktifitas sehari-hari.

\section{Kata kunci: Perkembangan, Banjar, Belaluan Sadmerta, Kota Denpasar, Otonomi Daerah.}

\section{Latar Belakang}

Pada tahun 1918 dari modal pinjaman seperangkat alat gong Puri Dangin terbentuklah sekaa gong Belaluan sebagai cikal bakal berkesenian di Denpasar khususnya warga banjar Belaluan. Semakin hari sekaa gong Belaluan mulai berkembang dan dikenal semua orang karena pertunjukkannya selalu menghibur masyarakat lewat kesenian tabuh atau musik tradisional, sekaa gong Belaluan mengalami puncak kejayaannya tahun 1951 pada saat dipimpin oleh I Wayan Beratha. Sekaa gong Belaluan mulai menunjukkan diri sebagai sekaa yang digemari dengan menggandeng beberapa penari dan penabuh dari banjar Gerenceng untuk mengikuti setiap pentasnya. Kesuksesan sekaa gong Belaluan dapat terlihat ketika menjadi perwakilan banjar Belaluan untuk mengisi acara hingga ke luar negeri seperti Tiongkok.

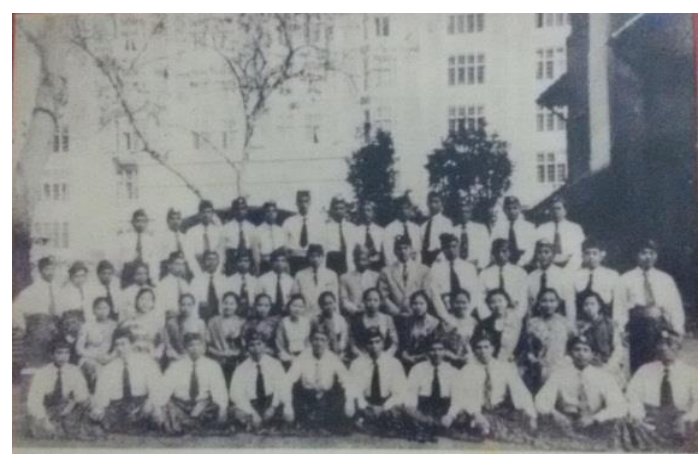

Gambar (1) Sekaa Gong Belaluan saat berada di Tiongkok tahun 1956

(I Nyoman Yudha, 2012b:29)

Setibanya dari Tiongkok terjadi hal yang tidak diduga-duga dalam kiprah sekaa gong Belaluan yang kemudian mempengaruhi masyarakat banjar
Belaluan pada tahun 1956. Masyarakat banjar Belaluan mulai terpecah belah karena suatu konflik yang terjadi di sekaa gong Belaluan. Masing-masing belah pihak memiliki pandangan tersendiri dari konflik yang terjadi sehingga tidak dapat dihindari terjadinya perpecahan.

Masyarakat banjar Belaluan yang awalnya tergabung dalam sekaa gong Belaluan memilih keluar dan membentuk kelompok baru yang bernama sekaa gong Sadmerta pada tahun 1957 (I Ketut Ardhana, 2018: 42). Lambat laun sekaa gong Sadmerta berkembang pesat dan memiliki pengaruh luas hingga dapat pentas ke luar negeri seperti ke New York, Amerika Serikat.

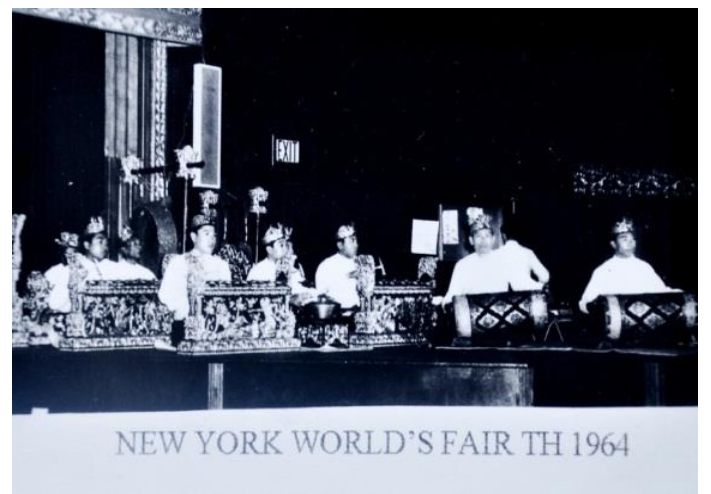

Gambar (2) Sekaa Gong Banjar Belaluan Sadmerta saat mengikuti New York World's Fair tahun 1964 (Arsip foto Anom Manik)

Untuk menunjang aktivitas seharihari sekaa gong Sadmerta, maka para penabuh yang tergabung berinisiatif membuat sebuah balai berkumpul warga banjar (Bale Banjar) baru yang terletak tidak jauh dari banjar Belaluan yaitu di jalan Rambutan Denpasar. Banjar baru ini dinamakan banjar Belaluan Sadmerta. 
Memasuki tahun 2001 merupakan awal yang baik bagi perkembangan suatu sistem sosial masyarakat lokal (banjar) karena hal ini sejalan dengan peraturan daerah Provinsi Bali Nomor 3, Tahun 2001 (I Gde Parimartha, 2013: 50-51). Sejauh ini peran banjar begitu penting namun tidak banyak terdapat kajiankajian yang berkaitan dengan banjarbanjar di Bali.

Karena itulah sesuai pemaparanpemaparan diatas penulis mengkaji peran banjar lebih mendalam melalui sebuah penelitian yang berjudul, "Perkembangan banjar Belaluan Sadmerta di Kota Denpasar tahun 1957-2017". Dalam penulisan ini, lebih disoroti dan akan dilihat sejauhmana perannya dalam konteks sosial, politik, agama dan ekonomi.

Hal menarik lainnya yang akan dibahas pada banjar Belaluan Sadmerta adalah adanya peran suatu sekaa yaitu sekaa gong dalam proses berdirinya banjar ini hingga menjadi banjar dengan organisasi yang kompleks.

\section{Pokok Permasalahan}

Sesuai dengan latar belakang di atas maka pertanyaan utama yang akan muncul yakni :

a) Faktor-faktor apa yang melatar belakangi berdirinya banjar Belaluan Sadmerta?

b) Bagaimana perkembangan banjar Belaluan Sadmerta dalam bidang sosial budaya, agama, ekonomi dan politik yang terjadi dalam kurun waktu 1957-2017?

\section{Tujuan Penelitian}

Adapun tujuan dari penelitian ini, sebagai berikut:

a) Untuk mengetahui latar belakang berdirinya banjar Belaluan Sadmerta.

b) Untuk mengetahui perkembangan banjar Belaluan Sadmerta dalam bidang sosial budaya, agama, ekonomi dan politik yang terjadi dalam kurun waktu 1957-2017.

\section{Metode Penelitian}

Pertama, tahap heuristik yaitu dalam hal ini penulis mencari dan mengumpulkan data dari sumber-sumber sejarah di lapangan baik itu sumber tertulis berupa buku, sumber dokumen foto atau sumber lisan dari hasil mewawancarai orang-orang yang mengetahui peristiwa tentang topik penelitian ini.

Tahap kedua, tahap kritik sumber, penulis melakukan penyaringan secara kritis terhadap sumber-sumber yang telah dikumpulkan terutama terhadap sumber primer atau sumber pertama. Kritik sumber dilakukan untuk memperoleh fakta yang menjadi pilihan dan dapat dipercaya kebenarannya.

Tahap ketiga, intepretasi yaitu penulis menafsirkan keterangan sumbersumber sejarah. Dalam hal ini penulis memberikan penafsiran terhadap fakta yang diperoleh selama melakukan penelitian di lapangan dengan cara menghubungkan fakta yang satu dengan fakta yang lain yang saling berkaitan. Semua fakta yang telah terangkum akan dijadikan sebagai bahan dalam penulisan ini.

Tahap keempat, historiografi merupakan hasil dari semua penulisan yang telah dilakukan sebelumnya. Disini penulis menulis cerita sejarah berdasarkan data yang telah dikumpulkan dan dianalisis sebelumnya (Helius Sjamsuddin, 2007:12-16).

\section{Hasil dan Pembahasan}

Penelitian ini menggunakan teori sejarah yang di kemukakan Ida Bagus Sidemen mengenai pengumpulan bukti kejadian sejarah seperti sejarah banjar Belaluan Sadmerta (Historical Explanation), pengumpulan fakta dari laporan dilapangan (Historical 
Objektivity), dan mencari tokoh-tokoh yang memiliki pengaruh dominan besar dalam membentuk lingkungan di dalam banjar Belaluan Sadmerta (Historical Determinism) guna merekontruksi faktorfaktor yang melatarbelakangi berdirinya banjar Belaluan Sadmerta kemudian perkembangannya dalam bidang sosial budaya, agama, politik dan ekonomi ( Ida Bagus Sidemen,1991:30-31).

\subsection{Faktor-faktor yang melatar belakangi berdirinya banjar Belaluan Sadmerta}

Ada dua faktor yang melatarbelakangi berdirinya banjar Belaluan Sadmerta yaitu faktor luar (Eksternal) dan faktor dalam (internal) dari tubuh sekaa gong Belaluan.

\subsubsection{Faktor Eksternal dalam sekaa gong Belaluan}

Faktor Eksternal merupakan faktor yang disebabkan dari luar tubuh sekaa gong Belaluan seperti peran warga atau krama banjar Belaluan dalam masalah keuangan dan rasa gotong royong.

\subsubsection{Masalah Keuangan}

Sekaa gong Belaluan telah dua kali mengalami masa-masa sulit selama kiprahnya berkesenian. Yang pertama, yaitu saat datang dari Batavia pada tahun 1929 dimana gamelan ditarik oleh pihak Puri Dangin. Yang kedua, setelah kembali dari Tiongkok di tahun 1956 dimana alat-alat gamelan dibekukan oleh pihak banjar (I NyomanYudha,2012a:3).

Diduga hal inilah yang mengakibatkan masalah keuangan tersebut terjadi dikarenakan para penabuh dan penari yang tergabung dalam sekaa gong Belaluan sangat bergantung dari seperangkat alat gamelan dalam mencari nafkah dengan pentas sehari-hari.

\subsubsection{Rasa Gotong Royong}

Banyak yang merasa bangga dengan kesuksesan sekaa gong Belaluan melalui kiprahnya pentas di dalam maupun di luar negeri. namun diduga tidak sedikit yang menyimpan rasa tidak suka atau iri hati dengan kesuksesan sekaa gong Belaluan.

Puncaknya pada tahun 1956 , sepulang dari Tiongkok. krama banjar dan beberapa anggota sekaa gong Belaluan justru memiliki sudut pandang yang berbeda-beda dan cenderung satu sama lain saling berseberangan dan berimbas pada rasa gotong-royong di setiap krama banjar dalam kegiatan sehari-hari di wilayah banjar Belaluan.

\subsubsection{Faktor Internal dalam Sekaa gong Belaluan dan proses berdirinya banjar Belaluan Sadmerta}

Faktor internal merupakan faktor yang terjadi di dalam sekaa gong Belaluan karena disebabkan anggota sekaa gong tersebut. Mengingat tidak semua anggota gong Belaluan bisa ikut serta ke Tiongkok, maka ada satu dua orang yang merasa tidak puas. Dari banjar Gerenceng misalnya, hanya lima orang yang bisa ikut serta. Mereka adalah Made Nida dan Ni Made Sungkreg selaku penari dan tiga oang penabuh, yakni Nyoman Renjing, Nyoman Geriya, dan Nyoman Repot.

Ditambah lagi dengan terjadinya pernikahan antar pemain, maka konflik dalam tubuh gong Belaluan meruncing menjadi perpecahan. Seorang penari Truna Jaya yang ikut serta dalam rombongan ke Tiongkok dinikahi oleh seorang penabuh.. Sejumlah anggota tidak bisa menerima keadaan itu, karena merasakan kehilangan seorang penari andalan yang belum ada penggantinya.

Mereka berasumsi, karena sudah menikah, Maka penari tersebut tidak akan bisa kembali menari bersama dengan gong Belaluan. Itu sesuai dengan peraturan yang berlaku, penari yang sudah menikah tidak boleh lagi ikut menari dengan gong Belaluan, sebab 
pikirannya sudah bercabang pada keluarga. Mereka mengatakan "asset" berharga Sekaa gong Belaluan telah direbut paksa, sedangkan beberapa pihak juga punya alasan, bahwa sepasang kekasih yang saling mencintai mempunyai hak untuk melanjutkan hubungan mereka dalam pernikahan. Karena sama-sama merasa benar, maka perpecahan gong Belaluan tidak terhindarkan.

Menurut I Wayan Senen, persengketaan antara warga banjar yang tergabung dan tidak tergabung dalam gong Belaluan juga dipicu oleh masalah keuangan dan rasa gotong royong (I Wayan Senen,2002:46).

Di tengah situasi tersebut, Puri Agung Belaluan menyanggupi memberikan ruang berkumpul dan beraktivitas sementara bagi sekaa gong Belaluan yang merasa tersisihkan di banjar Belaluan. Lambat laun, dilatari oleh kerinduan dan kesadaran berkreativitas, para seniman ini kemudian membentuk sekaa gong baru yang diberi nama Sekaa Gong Sadmerta. Nama "Sadmerta" yang dicetuskan oleh Anak Agung Ngurah Agung ini merupakan singkatan dari "Samia Adnyananing Merta" yang merefleksikan keteguhan hati dan solidaritas anggota sekaa gong untuk terus bersama-sama dalam meraih dan menjalankan kehidupan yang lebih baik (I Nyoman Yudha,2012a:1).

Setelah berjalannya waktu dengan modal pinjaman seperangkat gamelan dari Desa Anggabaya, Abiankapas Kaja serta Jero Kerobokan. Sekaa gong Sadmerta berhasil meraih sukses lewat pertunjukan keliling dari dalam negeri hingga ke Amerika dan Eropa. Kemudian kembali ke tanah air dan berkeinginan membeli sebidang tanah di jalan Rambutan Denpasar yang akan diperuntukkan untuk pembangunan bale banjar (I Nyoman Yudha,2012a:21).

Sudah sejak lama, anggota sekaa memupuk keinginan untuk mendirikan banjar baru, sebab bagi orang Bali pada umumnya keberadaan banjar sangat penting sebagai wadah suka-duka ( I Made Adhika,2015: 90). Sejumlah figur yang ikut berperan dalam pembentukan banjar yang diberi nama Belaluan Sadmerta ini diantaranya adalah : I Ketut Regig, I Gusti Made Suwena, I Wayan Badera, I Mangku Sukiya, I Wayan Surpha, I Wayan Beratha, Nyoman Yudha, Nyoman Darmada, Pan Mesir, Made Ruda, Ketut Patra, Ketut Suta, Anak Agung Ngurah Gede Sumatra, Anak Agung Alit Raka Janur, I Gusti Made Kondra, I Gusti Putu Pendra, Ketut Ampug, Nyoman Raneh, Ketut Rena, Anak Agung Ngurah Agung, Anak Agung Ngurah Suralaga, Anak Agung Raka Ruslan, Anak Agung Raka Mantri, Cokorda Bagus Sayoga dan lainnya.

\subsection{Perkembangan Banjar Belaluan Sadmerta dalam bidang Sosial Budaya, Agama, Politik dan Ekonomi}

Perkembangan banjar Belaluan Sadmerta dalam bidang sosial budaya, agama, politik dan ekonomi memiliki potensi yang dapat dipelajari guna menjadikan banjar sebagai wadah suatu komunitas untuk menuju penghidupan bersama yang lebih baik.

Adapun perkembangan banjar Belaluan Sadmerta bisa dilihat sebagai berikut:

\subsubsection{Bidang Sosial Budaya}

Struktur kepengurusan awal berdirinya banjar Belaluan Sadmerta hanya dijalankan oleh anggota sekaa gong saja tetapi di tahun 2017 beberapa hal pendukung aktifitas sosial budaya sehari-hari banjar Belaluan Sadmerta tergabung dalam beberapa kelompok masyarakat atau sering disebut sekaa diantaranya :

a) Sekaa Gong Sadmerta

b) Sekaa Teruna Teruni Belaluan Sadmerta 
c) PKK

d) Sekaa Gong Laras Sakti

e) Sekaa Pesantian lila Samghita

Hal lain yang perlu diingat dan diketahui semua orang bahwa di setiap banjar yang ada di Bali juga mewadahi kelompok khusus untuk para lansia yang menjadi krama Banjar dalam beraktifitas. Di banjar Belaluan Sadmerta juga terdapat kegiatan Denpasar City Heritage Tour sebagai kegiatan untuk melestarikan dan memperkenalkan budaya Bali.

\subsubsection{Bidang Agama}

Pada awalnya tahun 1957 Pura Banjar Belaluan Sadmerta, telah menjadi tempat (berstana) Ratu Ayu Mas Sekar Taji dan Ratu Gede Bawi Muka yang dulunya diletakkan di bale pengiasan pura keluarga (merajan) Puri Agung Belaluan dikarenakan pada saat itu bale banjar Belaluan Sadmerta masih dalam tahap pembangunan.

Pada tahun 1962 Setelah adanya perebah atau trans salah satu krama banjar Belaluan Sadmerta, saat itu dikatakan harus ada stana Ratu Ayu Ibu maka dibuatkanlah salah satu stana lagi yaitu Ratu Ayu Ibu.

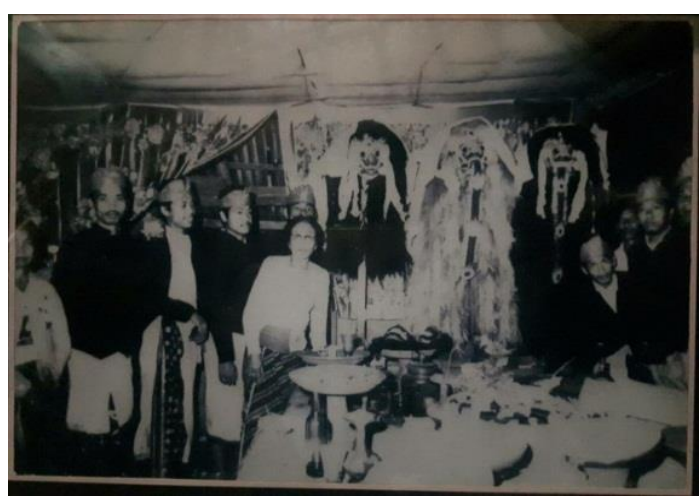

Gambar (3) Sesuhunan Ratu Ayu Ibu,

Ratu Ayu Mas Sekartaji, Ratu Gede Bawi

Muka yang di letakkan di Bale

Pengiasan Puri Agung Belaluan tahun 1962

(Arsip foto Turah Made Kembar)
Setelah tahun 1977 dimana renovasi pembangunan bale banjar Belaluan Sadmerta dibuat bertingkat maka Ratu Ayu Ibu, Ratu Ayu Mas Sekar Taji dan Ratu Gede Bawi Muka dipindahkan ke bale gedong Pura Banjar yang letaknya di lantai dua, serta dibuatkan lagi stana baru yaitu stana Ratu Bhagawan Penyarikan. Keempat stana tersebut oleh krama banjar dijadikan sebagai manifestasi Ida Sang Hyang Widhi Wasa.

Disamping itu, pada setiap Tilem Kelima, Ratu Ayu Ibu, Ratu Ayu Mas Sekar Taji, dan Ratu Gede Bawi Muka melakukan perjalanan keliling di sekitar wilayah Banjar Belaluan Sadmerta, dengan melalui minimal tiga persimpangan jalan dan maksimal tujuh persimpangan. Bila cuaca sedang baik, tentunya ritual di tujuh perempatan jalan akan dilakukan, tetapi terkadang tidak sampai tujuh, terutama bila keadaan tidak memungkinkan seperti hujan lebat atau ada orang meninggal di jalan yang biasanya dilewati.

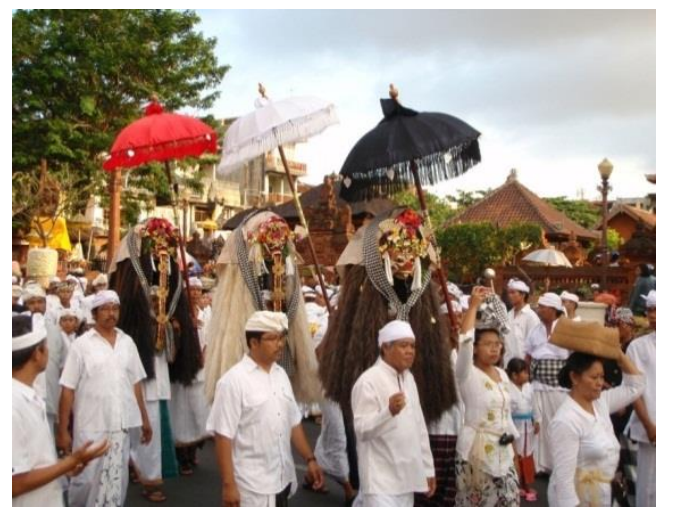

Gambar (4) Ratu Ayu Ibu, Ratu Ayu Mas Sekar Taji, dan Ratu Gede Bawi Muka melakukan perjalanan keliling di sekitar wilayah Banjar Belaluan Sadmerta tahun 2017

(Arsip foto Anom Manik)

Pada awalnya upacara adat (piodalan) di Pura Banjar Belaluan Sadmerta dilaksanakan dua kali yakni pada Tumpek Landep dan Tumpek Krulut. Namun berdasarkan keputusan 
banjar, kedua piodalan dilaksanakan bersamaan hanya pada satu hari terpilih yakni setiap Tumpek Krulut atau dalam kalender Bali jatuh pada Sabtu Kliwon Wuku Krulut.

\subsubsection{Bidang Politik}

Setelah kemerdekaan Indonesia pada tanggal 17 Agustus 1945, Cokorda Bagus Sayoga dari perwakilan Puri Satria Denpasar membawa surat kesetiaan kepada Presiden Soekarno, bahwa meskipun di Bali berkembang Negara Indonesia Timur (NIT), akan tetapi Puri Satria tetap setia kepada Republik Indonesia yang sah. Melihat kekayaan seni budaya di banjar Belaluan Sadmerta ini kemudian Soekarno pun memperkenalkan banjar ini kepada dunia internasional. Bahkan, pada masa kekuasaan Orde Lama terutama setelah pemilihan umum pertama tahun 1955 hingga 1967 seniman tabuh dan tari banjar Belaluan Sadmerta semakin melalang buana ke luar negeri.

Adapun sebagai gambaran, kegiatan politik di Bali dan khususnya di Denpasar, sudah mulai merebak pasca pengakuan kedaulatan tahun 1949. Berbagai partai menyebarkan ideologi dan pengaruhnya, terutama menjelang pemilihan umum untuk parlemen maupun penentuan konstituante tahun 1955. Pendekatan kultural pun diambil sebagai strategi kampanye, salah satunya menyasar organisasi tradisional serupa banjar dan sekaa. Tiga partai yang paling menonjol dalam pemilu pertama tersebut adalah Partai Nasional Indonesia (PNI), Partai Sosialis Indonesia (PSI), dan Partai Komunis Indonesia (PKI) (Geoffrey Robinson, 2006: 298-299). Pasca pemilihan umum suhu persaingan antara ketiga partai ini terus memanas, dan tak pelak juga berpengaruh hingga tataran masyarakat di komunitas sosial terkecil seperti banjar maupun sekaa-sekaa di bawahnya.
Penggunaan seni teater dan gamelan sebagai media propaganda pada era 1950an dan 1960an menyebabkan banyaknya korban Tragedi 1965 dari kalangan seniman yang pernah bermain di acara Lembaga Kebudayaan Rakyat (Lekra) yang di gagas oleh PKI (Hideharu Umeda,2007:46).

Dimulainya era Orde Baru 1968 hingga 1998 tampak peran kelompok masyarakat biasa lebih dominan, sementara puri yang dianggap proSoekarno saat itu karena sebagian besar pendukung Partai Nasional Indonesia (PNI) karena pendirinya adalah Cokorda Ngurah Agung, dapat dikatakan diabaikan dalam kancah poltik Orde Baru. Meskipun demikiian, bukan berarti puri tidak memainkan peranan penting, karena di kalangan puri juga ada yang menjadi elit politik di partai Golongan Karya (Golkar) yaitu Cokorda Ngurah Mayun Samirana atau Raja Denpasar IX dan ada dari krama banjar Belaluan Sadmerta pada era reformasi yaitu I Ketut Suwandi.

Berakhirnya Orde Baru tahun 1998, membuka peluang baru bagi Puri Satria untuk tampil di bidang politik yaitu dengan berhasilnya Anak Agung Ngurah Oka Ratmadi (Cok Rat) sebagai Bupati Badung dan di era Reformasi saat ini dengan tampilnya Anak Agung Ngurah Puspayoga sebagai Menteri Usaha Kecil dan Menengah (UKM) dalam masa pemerintahan Joko Widodo dan Yusuf Kala.

\subsubsection{Bidang Ekonomi}

Pada awal tahun 1950, orang-orang Bali telah berjualan patung-patung dan lukisan kepada turis. Ada yang memasarkan dengan cara langsung menghampiri lalu mengacungkan barang ke konsumen atau yang kerap disebut "dagang acung" yang sebenarnya sudah ada sejak era 1930-an. Namun ada juga yang membuat suatu bisnis artshop atau toko barang kesenian yang berdiri di 
dekat daya tarik wisata maupun penginapan (Michel Picard, 2006: 8788).

Salah seorang yang dipandang sebagai pelopor dari perkembangan bisnis ini adalah $\mathrm{Ni}$ Nyoman Rapeg dengan tokonya yang bernama Sutji Artshop berlokasi di Jalan Ngurah Rai (kini Jalan Veteran) Denpasar. Inilah yang kemudian turut berpengaruh terhadap kemunculan bisnis-bisnis serupa di Kota Denpasar (Adrian Vickers, 2012:3). Adapun Ni Nyoman Rapeg sendiri dulunya merupakan krama banjar Belaluan yang kini generasinya menjadi krama banjar Belaluan Sadmerta. Dapat dilihat bahwa orang lokal juga ikut menjadi pemain bahkan pelopor dalam sektor ekonomi khususnya perkembangan artshop di Bali.

Artshop ini memiliki peran yang sangat penting dalam perekonomian Banjar Belaluan maupun Banjar Belaluan Sadmerta. Walaupun tidak disebutkan jumlah uang sewa atau iuran yang diberikan pemilik artshop tetapi jika ada kegiatan di banjar seperti pembangunan Bale Banjar, kegiatan upacara adat dan Lain-lain. Artshop selalu memberikan bantuan dana.

Memasuki era reformasi tepatnya tahun 2010 di kota Denpasar, pada bulan Desember selalu dilaksanakan sebuah acara setiap tahunnya. Acara tersebut dinamakan Denfest atau Denpasar Festival. Denfest memberikan sebuah masukan besar bagi pemerintah kota Denpasar secara finansial tidak terkecuali banjar-banjar yang terkena dampak dari acara tersebut seperti banjar Belaluan Sadmerta di karenakan letak wilayahnya. Kedatangan pengunjung Denfest yang sangat banyak membuka sebuah peluang bagi banjar untuk ikut aktif memperoleh masukan finansial lewat jasa parkir.

\section{Simpulan}

Perkembangan banjar Belaluan Sadmerta bisa dikatakan tidak terlepas dari peran sekaa gong Sadmerta dalam upaya untuk meneruskan nilai kebersamaan dari tahun 1957 dan tetap melestarikan budaya yang tumbuh berkembang di setiap zaman. Hal ini penting, sebab menjaga keguyuban adalah salah satu cara untuk terus mengembangkan banjar dan diri pribadi krama atau warga, baik para warga lokal yang tinggal di wilayah banjar (krama arep) maupun warga pendatang (krama tamiu) di tengah perubahan yang terjadi saat ini dan di masa mendatang. Di sisi lain, komunitas banjar, dalam hal ini banjar Belaluan Sadmerta, memiliki potensi besar sebagai penentu arus perubahan ke arah yang lebih baik.

Beberapa pengetahuan tentang perjalanan berkembangnya banjar Belaluan Sadmerta dapat dilihat dari bidang sosial budaya seperti sekaa gong,sekaa teruna teruni, sekaa santi, kegiatan PKK, kegiatan Lansia dan Denpasar City Heritage Tour.

Adapun hal lain yang dapat dilihat dari perkembangan banjar Belaluan Sadmerta antara lain bidang Agama melalui praktek penyungsungan. bidang Politik melalui adanya peran dan pengaruh tokoh-tokoh penting dalam membentuk lingkungan krama banjar Belaluan Sadmerta yang lebih maju, dan yang terakhir bidang Ekonomi melalui peranan mata percaharian krama banjar Belaluan Sadmerta berupa artshop dan penyediaan jasa parkir Denpasar festival dalam meningkatkan keuangan banjar Belaluan Sadmerta.

\section{Saran}

Dalam hal pengelolaan, Seluruh pihak terkait harus selalu melakukan pembinaan melalui inovasi dan pengembangan yang mengikuti zaman tetapi tidak melupakan identitas budaya daerah yang ada. Selain itu, diharapkan nantinya Banjar sebagai wadah suatu komunitas di Bali menjadi identitas masyarakat yang dapat kian dijaga 
keberadaannya dan dimiliki dengan rasa kepedulian yang besar sebagai warisan bersama yang harus dilestarikan, bahkan dikembangkan. Dengan demikian, nantinya dapat semakin bermanfaat bagi masyarakat sekaligus mendukung program pemerintah tanpa mengesampingkan nilai-nilai yang selama ini diamini bersama dan relevan dengan perkembangan zaman.

\section{Daftar Pustaka}

Adhika, I Made. 2015. Banjar \& Konsep Komunitas di Bali. Denpasar: Udayana University Press.

Ardhana, I Ketut.2018. Banjar Belaluan Sadmerta : Penyangga Kota Pusaka Denpasar.Denpasar: Universitas Hindu Indonesia.

Helius Sjamsuddin. 2007. Metodologi Sejarah.Yogyakarta : Ombak.

Parimartha, I Gede. 2013. Silang Pandang Desa Adat Dan Desa Dinas Di Bali. Denpasar : Udayana University Press.

Picard, Michel. 2006. Pariwisata Budaya dan Budaya Pariwisata. Jakarta: Kepustakaan Populer Gramedia.

Robinson, Geoffrey. 2006. Sisi Gelap Pulau Dewata: Sejarah Kekerasan Politik. Yogyakarta: LKIS.

Senen,I Wayan.2002.Wayan Beratha Pembaharu Gamelan Kebyar Bali. Yogyakarta: Terawang Press.

Sidemen,Ida Bagus.1991. Lima Masalah Pokok dalam Teori Sejarah, dalam Widya Pustaka Tahun VII Nomor 2 januari 1991.Denpasar : Fakultas Sastra Universitas Udayana.
Umeda, Hideharu. 2007. "Cultural Policy on Balinese Performing Arts: The First Decade of LISTIBIYA," dalam Y. Terada (ed.), Authenticity and Cultural Identity Senri Ethnological Reports 65, tahun 2007. Diakses via minpaku.ac.jp

Vickers, Adrian. 2012. Bali: A Paradise Created. Singapore: Tuttle Publishing.

Yudha, I Nyoman. 2012a. Kilas Balik Sekaa Gong Sadmerta: Sebagai Duta Budaya Indonesia Pada New York World Fair Tahun 1964: Membedah Pasifik Menuju Amerika, Melintasi Atlantik Menuju Eropa. Surabaya: Paramita.

Yudha, I Nyoman. 2012b. Legenda Gong Belaluan: Mengemban Misi Kenegaraan RI dalam Perjalanan Mengelilingi Negeri China. Surabaya: Paramita. 